\title{
Accumulation of polychlorinated biphenyls in furbot (Scophthalmus maximus) from seawater sediments and food
}

\author{
W. A. M. Courtney ${ }^{1} \&$ W. J. Langston ${ }^{2}$ \\ 1 Zoology Department, Westfield College, University of London; \\ London NW3 7ST, England, \\ and \\ 2 The Laboratory, Marine Biological Association, Citadel Hill, Plymouth; \\ PL1 2 PB, England
}

\begin{abstract}
Juvenile turbot, Scophthalmus maximus (L.), were exposed to $0.58 \mu \mathrm{g} \mathbf{1}^{-1}$ Aroclor 1254 in seawater, to sediments containing 100,60 and $1 \mathrm{ppm}$ or fed with cockle containing $20 \mathrm{ppm}$ PCB (polychlorinated biphenyls). Concentration factors for liver and muscle were $10^{4}$ and $10^{3}$, respectively, for uptake of PCB from seawater. Contamination of muscle was similar to that of sediments containing 1 and $60 \mathrm{ppm}$ PCB to which turbot were exposed, but less than the $20 \mathrm{ppm}$ in their experimental diet. Contamination of flatfish in the North Sea area is compared with the levels of PCB in the flounder, Platichthys flesus (L.), in the River Thames and predictable values for uptake of PCB from different pathways discussed.
\end{abstract}

\section{INTRODUCTION}

Benthic fish of commercial importance are sampled during monitoring of nearshore ecosystems and, sometimes, attempts are made to evaluate different routes of entry of PCB (polychlorinated biphenyls) into fish by comparison of their residues with those of sediments, seawater or lower trophic levels (for review see Addison, 1976).

Seawater of the more contaminated areas in the northern hemisphere, for example, in the Gulf of Catalina, south of Los Angeles, contains $35.6 \mathrm{ng} 1^{-1}$ (Scura \& McClure, 1975) and, usually, sediments are more contaminated.

Trophic amplification of organochlorines, when concentrations are expressed as wet weight, is less apparent when concentrations are based on lipid weights (e. g. Ten Berge \& Hillebrand, 1974; for review see Phillips, 1978). On the other hand, concentration factors for uptake of PCB from seawater in laboratory fish may be high, for example, $10^{5}$ in sheepshead minnows, Cyprinodon variegatus (Hansen et al., 1975).

This paper deals with investigations of the uptake of PCB in turbot from various sources of contamination in laboratory systems. They are part of a wider programme of quantitative and qualitative studies of PCB's in shallow marine benthic ecosystems. 


\section{MATERIAL AND METHODS}

Cerastoderma edule (L.) collected from Southend-on-Sea, Essex (R 882847, Ordnance Survey Sheet 178) during 1977 were subsampled to determine field values of polychlorinated biphenyl (PCB) residues and the remaining animals were held at $10^{\circ} \mathrm{C}$ $\pm 1 \mathrm{C}^{\circ}$ in a marine aquarium for about 6 days before use. Cockles were prepared as food containing PCB for experimental fish by placing them in silinised glass tanks of stirred seawater ( 30 revs $\mathrm{min}^{-1}$ ) at $10^{\circ} \mathrm{C} \pm 1 \mathrm{C}^{\circ}$ containing $0.25 \mathrm{mg} \mathrm{l}^{-1}$ Aroclor 1254 (Monsanto Chemicals Ltd.) adsorbed to the surface of alumina particles after the method of Courtney \& Denton (1976). The particulate feeding bivalves accumulated suitable quantities of PCB after 10 days when they were subsampled for residue analysis and the remainder stored at $-20^{\circ} \mathrm{C}$ until required for dosing fish.

Small turbot, Scophthalmus maximus (L.) (weight 71-160 g) taken in shallow water near Lowestoft, Suffolk (R 542910, Ordnance Survey Sheet 134) were subsampled for analysis and the remainder placed in aerated stirred seawater in silinised glass tanks at $15{ }^{\circ} \mathrm{C} \pm 1 \mathrm{C}^{\circ}$. The fish were fed approximately $1 / 3$ their body weight of cockles contaminated with Aroclor 1254 over a period of 8 to 14 days. It had been established that this weight of food approximated to the maintenance requirement of these animals under laboratory conditions. Residual cockle was removed from the tanks 15 min after feeding and the seawater was continuously filtered with a rotary pump (Eheim 383) containing $10 \%$ by weight beads of expanded polystyrene foam in activated charcoal. Subsequently, some fish were held in filtered seawater for periods of up to 6 months during which time they were either starved or fed with fresh cockle. Fish were subsampled throughout the experiment; the seawater was changed each fortnight and the filters were recharged once a month.

Further turbot were exposed to 100,60 and $1 \mathrm{ppm}$ of Aroclor 1254 on sand prepared by a method similar to that used by Courtney \& Denton (1976) to adsorb PCB onto alumina. These fish were sacrificed after 15 days in silinised glass tanks containing $3 \mathrm{~kg}$ of contaminated sand in 201 of seawater. Fish liver and muscle were analysed together with water and sand residues.

Turbot were also analysed after 15 days exposure to seawater containing $0.58 \mu \mathrm{g}^{-1}$ Aroclor 1254. Seawater was circulated continuously at $441 \mathrm{~h}^{-1}$ over contaminated sand $(60 \mathrm{ppm})$ and through the experimental tank, without sand, such that fish were exposed to $0.52 \mu \mathrm{g} 1^{-1}$ initially rising slightly to $0.63 \mu \mathrm{g} 1^{-1}$ after 15 days.

For comparison with laboratory results, the field data were supplemented by analysis of flounder (Platichthys flesus of 104-413 g, wet wt) taken from the screen of Thurrock Power Station on the Thames, Essex (R 592771, Ordnance Survey Sheet 177).

Residues extracted in hexane, were analysed with a Pye Series 104 Chromatograph with ${ }^{63} \mathrm{Ni}$ electron capture detectors and equipped with $83 \times 0.3 \mathrm{~cm}$ (inner diameter) glass columns packed with $1.3 \%$ Apiezon L $+0.2 \%$ E1001 on Chromosorb G A/W DCMS. Operating conditions were: column $190{ }^{\circ} \mathrm{C}$, detector $220^{\circ} \mathrm{C}$, gas flow, purified nitrogen, $60 \mathrm{ml} \mathrm{min}^{-1}$. Quantification of $\mathrm{PCB}$ was by comparison of peak heights with standard solutions expressed as ppm wet weight unless otherwise stated. 


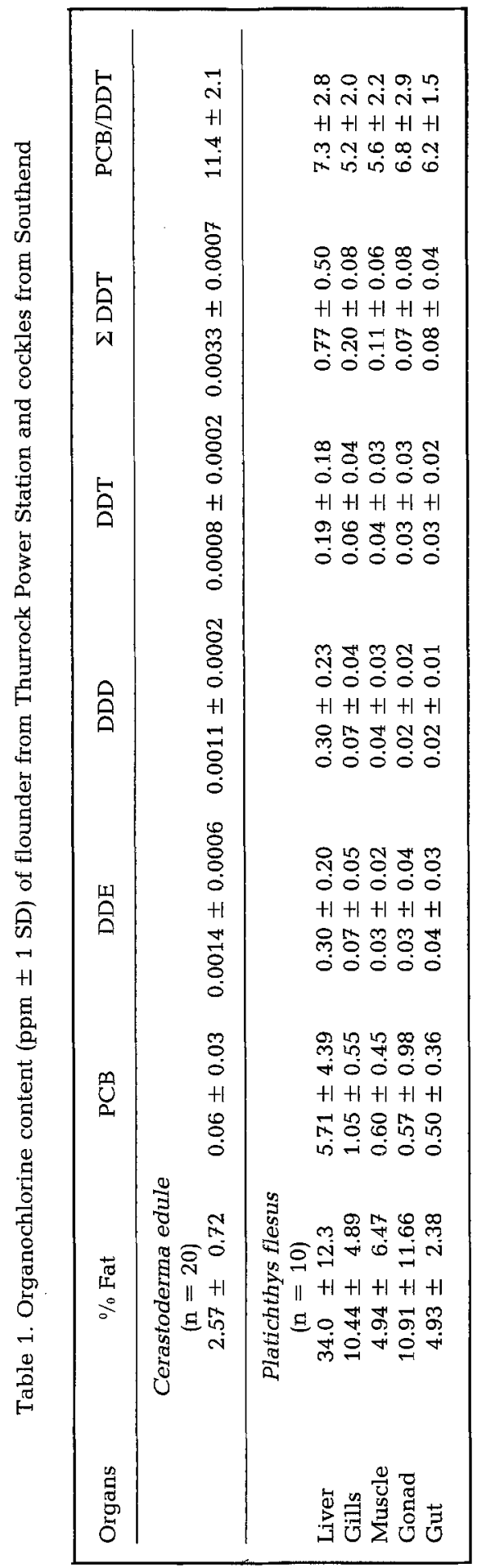




\section{RESULTS}

Cockles from Southend contain $0.06 \pm 0.03 \mathrm{ppm}$ (whole animal) $\mathrm{PCB}$; this is more than $10 \times$ the DDT content (Table 1). Thames flounder contain more PCB with $5.71 \pm$ $4.39 \mathrm{ppm}$ in the liver, which is more contaminated than all of the other tissues including muscle with $0.60 \pm 0.5 \mathrm{ppm}$ (Table 1). PCB : DDT ratios were lower in fish than in cockles ranging between 5.2 and 7.3 for different tissues.

High levels of PCB in flounder liver are associated with high lipid content and there is a correlation between PCB and lipid content in the different tissues of the flounder. Notably, although the values of PCB in the muscles of the flounder are $10 \times$ that in whole cockles, the ratio of the respective ether/extractable fat levels is 2:1 (Table 1).

Cockles exposed to $0.25 \mathrm{mg}^{1^{-1}}$ Aroclor 1254 on alumina particles accumulated 19.87 $\pm 8.74 \mathrm{ppm}$ PCB wet weight in their tissues after 10 days. When these were fed to turbot $(\overline{\mathrm{M}} \mathrm{PCB}$ in liver $=1.48$ and muscle $=0.44 \mathrm{ppm})$ at $1 / 3$ their body weight for a period of a fortnight, the fish developed residues of $33.95 \pm 10.74 \mathrm{ppm} \mathrm{PCB}$ in the liver and $4.17 \pm$ $2.11 \mathrm{ppm}$ in the muscle (Table 2). Subsequently these levels were maintained in fish

Table 2. PCB content (ppm $\pm 1 \mathrm{SE}$ ) of turbot during post-exposure having been fed with cockle containing 20 ppm Aroclor 1254

\begin{tabular}{|lcc|}
\hline Depuration & Turbot liver & Turbot muscle \\
\hline 2 days & $33.95 \pm 10.74$ & $4.17 \pm 2.11$ \\
1 month & $50.67 \pm 2.49(19.00 \pm 5.34)$ & $6.56 \pm 4.22(1.95 \pm 0.46)$ \\
3 months & $38.64 \pm 16.50$ & $3.85 \pm 1.42$ \\
6 months & $-(9.35)^{*}$ & $-(1.75 \pm 0.89)$ \\
Figures in parentheses relate to starved individuals & \\
${ }^{*} \mathrm{n}=1$ & & \\
\hline
\end{tabular}

Table 3. PCB budgets when turbot held on contaminated sediments for 15 days

\begin{tabular}{|c|c|c|c|c|c|c|}
\hline PCB in: & Sand & Water & liver & $\begin{array}{l}\text { Turbot } \\
\text { muscle }\end{array}$ & total & Total PCB \\
\hline Initial & 300 $\mathrm{mg}(100 \mathrm{ppm})$ & - & * & ** & & $300 \mathrm{mg}$ \\
\hline Final & $174 \mathrm{mg}$ & $24 \mu \mathrm{g}$ & $469.37 \pm 125.39$ & $43.48 \pm 8.91$ & $13.8 \mathrm{mg}$ & $\begin{aligned} & 187.8 \mathrm{mg} \\
= & 63 \% \text { recovery }\end{aligned}$ \\
\hline Initial & $180 \mathrm{mg}(60 \mathrm{ppm})$ & - & $*$ & $* *$ & & $180 \mathrm{mg}$ \\
\hline Final & $150.6 \mathrm{mg}$ & $12.6 \mu \mathrm{g}$ & $179.77 \pm 39.85$ & $58.64 \pm 11.09$ & $1.3 \mathrm{mg}$ & $\begin{aligned} & 151.9 \mathrm{mg} \\
= & 84 \% \text { recovery }\end{aligned}$ \\
\hline Initial & $3 \mathrm{mg}$ & - & $*$ & $* *$ & & $3 \mathrm{mg}$ \\
\hline Final & $1.1 \mathrm{mg}$ & $3 \mu \mathrm{g}$ & $21.84 \pm 9.39$ & $1.89 \pm 0.36$ & $0.2 \mathrm{mg}$ & $\begin{aligned} & 1.3 \mathrm{mg} \\
= & 43 \% \text { recovery }\end{aligned}$ \\
\hline \multicolumn{7}{|c|}{$\begin{array}{l}\text { Total PCB residues in turbot after exposure represents an estimate based on PCB content of the } \\
\text { muscle and liver }\end{array}$} \\
\hline \multicolumn{7}{|c|}{${ }^{*} 1.48$ and ${ }^{* *} 0.44 \mathrm{ppm}$ in pooled control animals } \\
\hline
\end{tabular}


Table 4. Concentration factors for turbot tissues following uptake of PCB from different sources

\begin{tabular}{|c|c|c|}
\hline $\begin{array}{c}\text { External PCB level } \\
\text { on day } 1\end{array}$ & $\begin{array}{c}\text { Muscle (liver) } \\
\text { concentration }(\mathrm{ppm}) \\
\text { on day } 14 / 15\end{array}$ & $\begin{array}{c}\text { Concentration } \\
\text { factor }\end{array}$ \\
\hline $0.58 \mu \mathrm{g} 1^{-1}$ seawater & $2(25)$ & $6(50) \times 10^{3}$ \\
\hline $100 \mathrm{ppm}$ sediment & $43(469)$ & $0.4(4.7)$ \\
\hline $60 \mathrm{ppm}$ sediment & $59(180)$ & $1(3)$ \\
\hline $1 \mathrm{ppm}$ sediment & $2(22)$ & $2(22)$ \\
\hline $20 \mathrm{ppm}$ food & $4(34)$ & $0.2(1.7)$ \\
\hline
\end{tabular}

held for 3 months without food. However, fish which were fed on freshly collected cockles rid themselves of $3 / 4$ of their body load of PCB (Table 2).

Fish in tanks with sediment initially containing 100, 60 and 1 ppm Aroclor 1254 developed liver residues of $469.37 \pm 125.39,179.77 \pm 39.85$ and $21.84 \pm 9.39 \mathrm{ppm}$ PCB, respectively, after 15 days. By the end of the experiment the sediments contained 58 , 50.2 and $0.35 \mathrm{ppm}$ with $1.2,0.63$ and $0.15 \mu \mathrm{g} 1^{-1} \mathrm{PCB}$ in the seawater, respectively. Budgets for the contaminated sediments experiments given in Table 3 show that between 43 and $84 \%$ of the PCB introduced into the aquaria was recovered.

Aroclor 1254 contaminated seawater prepared by passing seawater over sand containing PCB gave a $\overline{\mathrm{M}}$ concentration of $0.52 \mu \mathrm{g} 1^{-1} \mathrm{PCB}$ in seawater. The $\overline{\mathrm{M}}$ concentration of PCB in the seawater entering and leaving the tanks containing the fish was $0.58 \mu \mathrm{g} 1^{-1}$ and turbot liver and muscle contained $24.88 \pm 7.25$ and $1.93 \pm 0.08$, respectively, after 15 days.

Concentration factors for liver and muscle of turbot contaminated with Aroclor 1254 by various methods are shown in Table 4.

\section{DISCUSSION}

Cockles and flounder of the outer Thames are slightly more contaminated with PCB than cockles and Solea solea in the Weser estuary (Goerke et al., 1979) although residues are of the same order of magnitude in both estuaries. PCB levels in flatfish of Swedish waters (Jensen et al., 1969), the Dutch Wadden Sea (Ten Berge \& Hillebrand, 1974), the Skagerrak (Eder et al., 1976) and the North Sea (Ten Berge \& Hillebrand, 1974; Schaeffer et al., 1976) contain less PCB than young turbot at Lowestoft. The liver of some very large specimens of flatfish from the English Channel (Ernst et al., 1976) is more contaminated.

PCB levels in the gut wall of Platichthys flesus taken at the Thurrock Power Station in May 1976 closely resemble levels in animals from the Medway estuary between March 1974 and April 1975 (Van den Broek, 1979).

Southend cockles have a similar level of PCB contamination to Mytilis edulis in the outer part of the Medway estuary (Wharfe \& Van den Broek, 1978) entering the southern reach of the River Thames and also to Mytilis edulis in Liverpool Bay (Riley \& Wahby, 1977). However, PCB residues are an order of magnitude greater in Mytilis edulis of the River Clyde (Holden, 1973), in New Brunswick waters (Zitko, 1971) and from the inner reaches of the Medway estuary (Wharfe \& Van den Broek, 1978). 
The solution of PCB obtained by passing seawater over Aroclor 1254 contaminated sand was an order of magnitude weaker than that obtained by mixing Aroclor 1254 and seawater using air (Courtney \& Langston, 1978). This difference in aqueous concentration reflects the affinity of PCB for active sites on the sand in the former system. Young turbot from Lowestoft which are less contaminated than Thames flatfish - possibly due to differences in size (Bache et al., 1972; Ernst et al., 1976) - accumulated similar amounts of PCB in their tissues whether in $0.58 \mu \mathrm{g} 1^{-1}$ seawater or on sand containing $1 \mathrm{ppm}$ Aroclor 1254 initially.

These results are reminiscent of earlier work with Arenicola marina and Nereis diversicolor which contained 0.39 and $0.49 \mathrm{ppm}$, respectively, after 10 days on $1 \mathrm{ppm}$ Aroclor 1254 in sand and accumulated similar body residues when held in $1.1 \mu \mathrm{g} \mathbf{1}^{-1}$ Aroclor 1254 in seawater (Courtney \& Langston, 1978).

Benthic fish, then, rapidly became contaminated with PCB from seawater with concentration factors of $10^{4}$ and $10^{3}$ for liver and muscle respectively (Table 4) compared with concentration factors of $10^{2}-10^{4}$ for uptake of PCB from seawater in other fish (Hansen et al., 1971; Hattula \& Karlog, 1973) and $10^{2}$ for pink shrimp, Penaeus duorarum (Nimmo et al., 1971a) and for polychaetes (Courtney \& Langston, 1978).

PCB levels in fish muscle were similar to respective sediment contamination of 1 or $60 \mathrm{ppm}$ whereas the PCB content of the liver was one order of magnitude greater with concentration factors of 22 and 3, respectively. These residues are 1 or 2 orders of magnitude greater than PCB levels in polychaetes in 1 ppm sand (Courtney \& Langston, 1978). Penaeus duorarum and $U_{c a}$ mimax differed by a factor of $<10$ from contaminated laboratory sediments (Nimmo et al., 1971b).

The seawater, gently stirred by aeration of tanks of turbot on contaminated sediment, itself contained PCB though clearly the PCB in the fish tissues came from the sediment, at least in part, since body loads exceeded those which would arise from such concentrations of PCB in seawater alone (Table 4).

In part due to the level of feeding, the fish muscle residues were 1 order of magnitude less than the PCB content of the contaminated food which was similar to the liver residues. Subsequently, PCB body loads were reduced to pre-experimental levels in fish which were fed with clean cockle $(0.06 \mathrm{ppm}$ PCB) but not in starved animals (Table 2). In goldfish and pinfish the $1 / 2$ life of PCB is 3 to 4 weeks (Hansen et al., 1971; Hattula \& Karlog, 1973) although rainbow trout retain $2 / 3$ of the PCB fed to them (Lieb et al., 1974).

In 1969 the liver of a dead flounder near the mouth of the Escambia River contained $187 \mathrm{ppm}$ PCB wet weight and 76 and $4.5 \mathrm{ppm}$ were present in the liver and muscle, respectively, of another dead specimen $5 \mathrm{~km}$ away in the Bay (Duke et al., 1970). A year later, levels in the sediments were $2.3 \mathrm{ppm}$ and seawater levels averaged $0.6 \mu \mathrm{g} 1^{-1} \mathrm{PCB}$ during 1969-71. In all probability contaminated sediments contributed to these fish kills. However, the concentration factors for turbot tissues in contaminated seawater in the laboratory (Table 4) suggest that similar residues might arise by uptake of PCB from seawater alone in the Weser River, for example, which contains 11-114 ng $1^{-1} \mathrm{PCB}$ (unpublished data quoted in Goerke et al., 1979).

Acknowledgements. This work was supported by Natural Environment Research Grant No. GR3/2101. 


\section{LITERATURE CITED}

Addison, R., 1976. Organochlorine compounds in aquatic organisms: their distribution transport and physiological significance. In: Effects of pollutants on aquatic organisms. Ed. by A. P. M. Lockwood. Cambridge Univ. Press, Cambridge, 127-144.

Bache, C. A., Serum, J. W., Youngs, W. D. \& Lisk, D. J., 1972. Chlorinated biphenyl residues: Accumulation in Cayuga Lake trout with age. - Nature, Lond. 177, 1191-1192.

Courtney, W. A. M. \& Denton, G. R. W., 1976. Persistence of polychlorinated biphenyls in the hardclam (Mercenaria mercenaria) and the effect upon the distribution of these pollutants in the estuarine environment. - Environ. Pollut. 10, 55-64.

Courtney, W. A. M. \& Langston, W. J., 1978. Uptake of polychlorinated biphenyl (Aroclor 1254) from sediment and from seawater in two intertidal polychaetes. - Environ. Pollut. 15, 303-309.

Duke, T. W., Lowe, J. I. \& Wilson, A. J., Jr., 1970. A polychlorinated biphenyl (Aroclor 1254) in the water sediment and biota of Escambia Bay, Florida. - Bull. environ. Contam. Toxicol. 5, 171-180.

Eder, G., Schaefer, R. G., Ernst, W. \& Goerke, H., 1976. Chlorinated hydrocarbons in animals of the Skagerrak. - Veröff. Inst. Meeresforsch. Bremerhaven 16, 1-9.

Ernst, W., Goerke, G., Eder, G. \& Schaefer, R. G., 1976. Residues of chlorinated hydrocarbons in marine organisms in relation to size and ecological parameters. I. PCB, DDT, DDE and DDD in fishes and molluscs from the English Channel. - Bull. environ. Contam. Toxicol. 15, 55-65.

Goerke, H., Eder, G., Weber, K., Ernst, W., 1979. Patterns of organochlorine residues in animals of different trophic levels from the Weser estuary. - Mar. Pollut. Bull. 10, 127-133.

Hansen, D. J., Parrish, P. R., Lowe, J. I., Wilson, A. J. \& Wilson, P. D., 1971. Chronic toxicity uptake and retention of Aroclor 1254 in two estuarine fishes. - Bull. environ. Contam. Toxicol. 6r $113-116$.

Hansen, D. J., Schimmel, S. C. \& Forester, J., 1975. Effects of Aroclor 1016 on embryos, fry, juveniles and adults of sheepshead minnows (Cyprinodon variegatus). - Trans. Am. Fish. Soc. 104, 584-588.

Hattula, M. L. \& Karlog, O., 1973. Absorption and elimination of polychlorinated biphenyls (PCB) in goldfish. - Acta pharmac. tox. 32, 237-245.

Holden, A. V., 1973. International co-operative study of organochlorine and mercury residues in wildlife 1969-71. - Pestic. Monit. J. 7, 37-52.

Jensen, S., Johnels, A. G., Olsson, M. \& Otterlind, G., 1969. DDT and PCB in marine animals from Swedish waters. - Nature, Lond. 224, 247-250.

Lieb, A. F, Bills, D. D. \& Sinnhuber, R. O., 1974. Accumulation of dietary polychlorinated biphenyls (Aroclor 1254) by rainbow trout (Salmo gairdneri). - J. Agric. Fd Chem. 22, 638-642.

Nimmo, D. R., Blackman, R. R., Wilson, A. J., Jr. \& Forrester, J., Jr., 1971a. Toxicity and distribution of Aroclor 1254 in the pink shrimp Penaeus duorarum. - Mar. Biol. 11, 191-197.

Nimmo, D. R., Wilson. P. D., Blackman, R. R. \& Wilson, A. J., Jr., 1971b. Polychlorinated biphenyl absorbed from sediments by fiddler crabs and pink shrimp. - Nature, Lond. 231, 50-52.

Phillips, D. J. H., 1978. Use of biological indicator organisms to quantitate organochlorine pollutants in aquatic environments - a review. - Environ. Pollut. 16, 167-229.

Riley, J. P. \& Wahby, S., 1977. Concentrations of PCB's Dieldrin and DDT residues in marine animals from Liverpool Bay. - Mar. Pollut. Bull. 8, 9-11.

Schaefer, R. G., Ernst, W., Goerke, H. \& Eder, G., 1976. Residues of chlorinated hydrocarbons in North Sea animals in relation to biological parameters. - Ber. dt. wiss. Kommn Meeresforsch. 24, 225-233.

Scura, E. D. \& McClure, V.E., 1975. Chlorinated hydrocarbons in seawater: Analytical methods and levels in the north-eastern Pacific. - Mar. Chem. 3, 336-346.

Ten Berge, W. F. \& Hillebrand, M., 1974. Organochlorine compounds in several marine organisms from the North Sea and the Dutch Wadden Sea. - Neth. J. Sea. Res. 8, 361-368.

Van den Broek, W. L. F., 1979. Seasonal levels of chlorinated hydrocarbons and heavy metals in fish and brown shrimps from the Medway estuary. - Environ. Pollut. 19, 21-38.

Wharfe, J. F. \& Van den Broek, W. L. F., 1978. Chlorinated hydrocarbons in macroinvertebrates and fish from the lower Medway estuary. - Mar. Pollut. Bull. 9, 76-79.

Zitko, V., 1971. Polychlorinated biphenyls and organochlorine pesticides in some freshwater and marine fishes. - Bull. environ. Contam. Toxicol. 6, 464-470. 